\title{
Upaya GoPay Terhadap Mahasiswa di Kantin UNTAR Kampus 1
}

\author{
Livia Gracely Wahyu, Eko Harry Susanto, Sisca Aulia. \\ gracely.livia@yahoo.com,ekos@fikom.untar.ac.id, siscaa@fikom.untar.ac.id
}

Fakultas Ilmu Komunikasi UNTAR

\begin{abstract}
As time hoes by, Technology and the economy creates new innovations that help human life, which is called financial technology (fintech). Financial Technology has a function to accelerate and facilitate various access to human finance. One of the companies in Indonesia that applies financial technology is GoJek. GoJek created GoPay as a financial technology that can be used to pay for all services in the GoJek application. However, now GoPay has developed and can be used in tenants who have collaborated with GoPay, such as Tarumanagara University Canteen Campus 1, which since 2019 has been working with GoPay so that students can transact using GoPay as a payment tool. Therefore, the researcher discusses GoPay's efforts in maintaining student purchase interest at Tarumanagara University. This research methodology is qualitative with a case study method based on the results of data from key informants / informants who have influence in this study. Based on the results of the interview, GoPay gave some efforts to students in the Tarumanagara University Campus 1 canteen.
\end{abstract}

Keywords: financial technology, gopay, purchase interest.

\begin{abstract}
Abstrak
Teknologi dan ekonomi yang berkembang seiring berkembangnya zaman menciptakan inovasi baru yang menolong hidup manusia, yang disebut dengan financial technology (fintech). Financial Technology memiliki fungsi untuk mempercepat dan mempermudah berbagai akses keuangan manusia. Salah satu perusahaan di Indonesia yang mengaplikasikan financial technology adalah GoJek. GoJek menciptakan GoPay sebagai financial technology yang dapat digunakan untuk membayar semua layanan di aplikasi GoJek. Namun, sekarang GoPay sudah berkembang dan dapat digunakan di tenant-tenant yang sudah bekerja sama dengan GoPay, seperti Kantin Universitas Tarumanagara Kampus 1 yang sejak tahun 2019 sudah bekerja sama dengan GoPay sehingga mahasiswa dapat bertransaksi menggunakan GoPay sebagai alat pembayarannya. Oleh sebab itu, peneliti membahas mengenai upaya GoPay dalam mempertahankan minat pembelian mahasiswa di Universitas Tarumanagara. Metodologi penelitian ini adalah kualitatif dengan metode studi kasus berdasarkan hasil data dari narasumber/ key informan yang memiliki pengaruh dalam penelitian ini. Berdasarkan hasil wawancara, GoPay memberikan beberapa upaya terhadap mahasiswa di kantin Universitas Tarumanagara Kampus 1.
\end{abstract}

Kata Kunci: financial technology, gopay, minat beli.

\section{Pendahuluan}

Susanto (2010) mengatakan bahwa perubahan sosial adalah cara kerja manusia yang berubah dalam menjalani kehidupan sehari-hari. Perubahan sosial terjadi karena adanya kemajuan dalam beberapa bidang seperti teknologi dan ekonomi. Teknologi dan ekonomi melahirkan inovasi baru yang menolong 
kehidupan manusia. Hal tersebut disebut sebagai financial technology. Financial technology adalah inovasi baru yang memenuhi kebutuhan individu di berbagai bidang seperti, jasa sistem pembayaran dari sisi instrumen, penyelenggara, mekanisme, maupun infrastruktur penyelenggaraan yang memproses transaksi pembayaran (Bank Indonesia, 2016).

Salah satu perusahaan di Indonesia yang mengaplikasikan financial technology adalah GoJek. GoJek adalah aplikasi penyedia jasa ojek online yang bekerja sama dengan para ojek konvensional dalam menyediakan jasa mengantar penumpang, makanan, maupun barang (www.gojek.com di akses pada 25 Agustus 2019). Salah satu fitur dari GoJek, adalah GoPay. GoPay adalah aplikasi uang elektronik yang dapat digunakan dalam bertransaksi keuangan melalui aplikasi gojek dan dapat digunakan oleh customer, maupun driver itu sendiri (sumber: https://www.gojek.com/blog/bayar-lebih-mudah-pakai-GoPay/ diakses pada tanggal 28 Agustus 2019), namun sekarang GoPay sudah berkembang dan dapat digunakan di tenant-tenant besar maupun kecil yang sudah bekerja sama dengan GoPay. Salah satu tenant yang sudah bekerja sama dengan GoPay adalah Kantin UNTAR Kampus 1. Kantin UNTAR (Universitas Tarumanagara) Kampus 1 berjalan seiring berkembangnya zaman, sehingga memutuskan untuk menggunakan salah satu metode pembayaran e-payment yaitu GoPay.

Berdasarkan uraian yang sudah terurai dari latar belakang diatas, identifikasi masalah yang terdapat dalam penelitian ini adalah: penggunaan GoPay di kalangan mahasiswa untuk berbelanja di kantin UNTAR Kampus 1, ada atau tidaknya minat pembelian mahasiswa menggunakan GoPay di kantin UNTAR dibandingkan dengan member card, dan melihat bagaimana penggunaan GoPay dapat mempertahankan minat pembelian mahasiswa Di Kantin UNTAR Kampus 1. Dengan demikian, maka permasalahan yang akan peneliti bahas dalam penelitian ini adalah: Bagaimana Upaya GoPay dalam Mempertahankan Minat Pembelian di Kantin UNTAR Kampus 1 ?

Penelitian ini menganut beberapa teori terkait yaitu: teknologi komunikasi, new media, e-payment. dan technology acceptance model. Teori yang sudah disebutkan didasari oleh kesesuaiannya dalam penelitian peneliti.

\section{Metode Penelitian}

Pada penelitian ini, peneliti menggunakan metode kualitatif. Peneliti mengumpulkan data dan informasi guna untuk melengkapi penelitian ini dengan cara wawancara mendalam bersama para key informan, dan juga informan yang menjadi acuan hasil penelitian ini. Narasumber dalam penelitian ini adalah:

- Ibu Wilina selaku, manager pengelola Kantin UNTAR Kampus 1.

- Ibu Windy Deasyanti, selaku pengelola Kantin UNTAR Kampus 1.

- Bapak Dr. Imam Nuraryo, M.A. (Comms), selaku Ahli Ilmu komunikasi.

- Christoefel Cahyadi, selaku mahasiswa UNTAR angkatan 2016 yang bertransaksi menggunakan GoPay di Kantin Universitas Tarumanagara Kampus 1.

- Christoefel Cahyadi, selaku mahasiswa UNTAR angkatan 2016 yang bertransaksi menggunakan GoPay di Kantin Universitas Tarumanagara Kampus 1 .

- Reynaldi Putra, selaku mahasiswa UNTAR angkatan 2016 yang bertransaksi menggunakan GoPay di Kantin Universitas Tarumanagara Kampus 1. 
Selain itu, untuk menyelesaikan penelitian ini, peneliti menggunakan metode studi kasus. Creswell (1998) menjelaskan bahwa studi kasus adalah suatu cara meneliti yang menekankan kepada eksplorasi suatu sistem yang terbatas pada sebuah kasus atau beberapa kasus secara detail, disertai dengan penggalian data secara mendalam yang melibatkan berbagai sumber informasi yang memiliki banyak konteks (Herdiansyah, 2010:76). Metode studi kasus akan membantu peneliti untuk mendapatkan hasil secara detail. Untuk memperoleh data secara kualitatif. Dalam penelitian ini, Pengumpulan data peneliti dapatkan menggunakan beberapa teknik yaitu: wawancara bersama narasumber, observasi non partisipan, data dan online. Selanjutnya, analisa yang peneliti gunakan untuk mengolah data dengan tahap berikut: reduksi data, penyajian data, serta penyimpulan dan evaluasi.

\section{Hasil Temuan dan Diskusi}

Hasil temuan yang peneliti dapatkan selama menyelesaikan penelitian ini tergolong menjadi 3, yaitu:

\section{Mahasiswa Aktif Menggunakan GoPay di Kantin UNTAR Kampus 1}

Berdasarkan hasil wawancara, Christoefel menyatakan bahwa dia aktif menggunakan GoPay sebagai metode pembayaran di Kantin UNTAR Kampus 1 apabila dia berada di kampus, dengan alasan karena dia menganggap GoPay memiliki kelebihan dalam bidang kemudahan, praktis, dan efisien. Selanjutnya, Yolanda beranggapan bahwa menggunakan GoPay lebih memudahkannya dalam bertransaksi dan juga tidak memakan waktu, serta GoPay memberikan cashback sebesar Rp 3.000,- dalam setiap transaksi.

GoPay sebagai satu-satunya metode pembayaran e-payment yang terdapat di Kantin UNTAR Kampus 1, telah meraih pengakuan sebagai aplikasi E-Wallet dengan pengguna terbanyak di Indonesia (Sumber: https://iprice.co.id/trend/insights/e-wallet-terbaik-di-indonesia/ Diakses pada tanggal 13 Desember 2019, pada pukul 23:03).

\section{Tingkat Kemudahan GoPay Lebih Menarik Minat Mahasiswa dalam bertransaksi di Kantin UNTAR Kampus 1.}

Berdasarkan hasil wawancara, Yolanda menyatakan bahwa top up saldo GoPay lebih mudah dilakukan dibandingkan dengan pengisian member card yang tersedia sebagai metode pembayaran lain di Kantin UNTAR Kampus 1. Christoefel juga menyatakan hal yang sama dan menjelaskan bahwa cara top up GoPay dapat dilakukan melalui aplikasi banking yang terdapat pada handphone masing-masing. Hal tersebut mengalahkan cara pengisian ulang saldo member card yang hanya bisa dilakukan secara manual dan juga hanya berlaku menggunakan uang tunai/ cash.

\section{Kantin UNTAR Sebagai Tempat Pertama GoPay Dalam Menerapkan QRIS Di Dunia Pendidikan}

Berdasarkan hasil observasi, UNTAR adalah perguruan tinggi pertama yang bekerja sama dengan GoPay menggunakan QRIS (Quick Response Code Indonesian Standart). Ibu Wilina, selaku manager pengelola Kantin Universitas Tarumanagara juga menjelaskan bahwa hadirnya GoPay di Kantin Universitas Tarumanagara adalah bentuk dukungan perguruan tinggi terhadap gerakan cashless yang sedang digencarkan di Indonesia. Hal ini tentunya sangat penting untuk mengetahui upaya 
apa saja yang diberikan GoPay terhadap mahasiswa di Kantin Universitas Tarumanagara Kampus 1.

Berdasarkan temuan yang sudah terurai, berikut adalah analisis peneliti:

\section{Penggunaan GoPay di Kalangan Mahasiswa UNTAR.}

Hadirnya GoPay ke dalam Kantin UNTAR dipengaruhi oleh universitas yang ingin memberikan advice kepada seluruh mahasiswa dalam menggunakan metode cashless dan juga maraknya penggunaan e-payment di seluruh tempat yang sangat menguntungkan pembeli (Sumber: Ibu Wilina, November 2019).

Melalui pernyataan yang diutarakan oleh narasumber pada temuan diatas, GoPay sudah berhasil mengait minat mahasiswa UNTAR untuk menggunakan nya sebagai metode pembayaran di Kantin Kampus 1 karena penggunaannya yang cepat dibandingkan dengan member card, dan juga benefit yang mereka sukai yaitu cash back. Cashback yang akan diterima oleh mahasiswa per transaksi sebesar Rp 3.000,di setiap satu merchant. Selain itu, GoPay menjadi satu-satunya metode e-payment yang ada di Kantin UNTAR karena beberapa alasan, yaitu: GoPay memiliki trend yang lebih tinggi di kalangan mahasiswa, GoPay bisa digunakan ke fitur GoJek lainnya dalam satu aplikasi, da GoPay memberikan cash back pastinya setiap hari (Sumber: Ibu Wilina, November 2019)

Analisis peneliti mengenai penggunaan GoPay di kalangan mahasiswa untuk berbelanja di kantin UNTAR Kampus 1 didasarkan oleh indicator pada teori technology acceptance model, yaitu Persepsi Manfaat (Perceived Usefulness). Persepsi manfaat secara jelas peneliti simpulkan sebagai pikiran yang mengartikan / menganggap bahwa menggunakan suatu teknologi akan sangat berguna untuk menambah kinerja, dan mempercepat pekerjaan yang ada, serta memberikan benefit kepada penggunanya.

Berdasarkan teori dan juga hasil wawancara yang sudah dilakukan, analisis yang peneliti simpulkan adalah, GoPay menyatakan manfaat nya melalui pemberian cashback kepada mahasiswa yang menggunakan GoPay dalam bertransaksi di Kantin UNTAR Kampus 1. Selain itu, Saldo GoPay juga dapat dimanfaatkan kedalam fiturfitur GoJek lainnya, yang juga memudahkan mahasiswa untuk memiliki satu aplikasi namun semuanya sudah tersedia di dalamnya. Hal ini juga diperkuat oleh pernyataan dari Dr. Imam Nuraryo M.A. (Comms) mengenai cashback dan kepraktisan yang dimiliki oleh E-payment.

\section{Minat pembelian mahasiswa menggunakan GoPay di kantin UNTAR dibandingkan dengan member card.}

Berdasarkan dari hasil wawancara bersama 2 narasumber peneliti yang rutin bertransaksi di Kantin UNTAR Kampus 1 pada temuan diatas, mereka berdua menyatakan lebih memilih GoPay dibandingkan dengan member. Hal ini diperkuat dengan pernyataan Ibu Wilina, selaku manajer Kantin UNTAR Kampus 1, bahwa mahasiswa dilihat lebih suka menggunakan GoPay karena menggunakan member card sulit di top up da nada uang jaminan sebesar Rp 10.000,- untuk jaminan kartu hilang atau tidak kembali. Sehingga, GoPay lebih unggul dari member card karena hal berikut: (1)Top up member card yang hanya bisa dilakukan secara manual di kasir yang sudah tersedia dan hanya bisa menggunakan uang cash. (2) GoPay memiliki cara yang lebih mudah dan efektif untuk mengisi ulang saldonya. Hal ini berkaitan dengan GoPay yang sudah bekerja sama dengan 28 institusi keuangan yang 
akan mempermudah user nya dalam hal melakukan top up yang bisa dilakukan melalui handphone dengan aplikasi mobile banking, SMS Banking, dan Internet Banking (Sumber : https://www.gojek.com/gopay/cara-top-up/ diakses pada tanggal 5 Desember 2019, pada pukul 21:10). (3) Bertransaksi dengan GoPay dianggap lebih mudah berkat kemajuan teknologi yang ada, yaitu menggunakan QR (Quick Response) Code yang sudah menjadi metode pembayaran GoPay semenjak April 2018.

Analisis peneliti terkait dengan minat pembelian mahasiswa menggunakan GoPay di kantin UNTAR dibandingkan dengan member card didasari oleh salah satu indikator yang terdapat dari teori technology acceptance model, yaitu persepsi kemudahan (perceived ease of use). Davis (1989) menyatakan bahwa perspektif kemudahan pengaplikasian (perceived ease of use) merupakan sebuah tingkatan dimana seseorang percaya bahwasanya penggunaan sistem tertentu, mampu mengurangi usaha seseorang dalam mengerjakan sesuatu. Persepsi kemudahan peneliti definisikan sebagai perspektif yang menganggap teknologi akan membuat segalanya lebih mudah dan tidak membebani khalayak (mahasiswa) dalam menggunakannya. Dengan kata lain, GoPay sudah memenuhi kriteria dari persepsi kemudahan melalui cara top up yang lebih mudah dan metode pembayaran yang menggunakan teknologi.

\section{Upaya Yang Diberikan GoPay Kepada Kantin Universitas Tarumanagara Kampus 1}

QRIS (Quick Response Code Indonesian Standart) yang memiliki standar Bank Indonesia dinyatakan dapat meningkatkan target pemerintah terkait inklusi keuangan di Indonesia. Penerapan QRIS di kantin UNTAR adalah pintu untuk penerapan QRIS di institusi pendidikan lainnya. Berdasarkan wawancara dengan manager pengelola kantin UNTAR 1, Ibu Wilina menyatakan bahwa pihaknya lebih tertarik bekerja sama dengan GoPay dibandingkan dengan e-payment lainnya, karena GoPay memiliki tren lebih besar dan saldo cashback dapat diterima ke dalam bentuk saldo kembali. Pernyataan tersebut juga sejalan dengan salah satu pendapat narasumber peneliti mengenai hadirnya GoPay sebagai metode bertransaksi di Kantin Universitas Tarumanagara Kampus 1, mereka menyatakan bahwa mereka lebih suka menggunakan GoPay karna hanya harus top up_di satu akun dan sudah dapat menikmati fitur lainnya.

Upaya GoPay terhadap mahasiswa di Kantin Universitas Tarumanagara dimulai dari sosialisasi pemanfaatan QRIS kepada seluruh rekan usaha (tenant), melalui berbagai penyuluhan langsung terhadap mitra kerja dan tenant-tenant. Melalui jalinan kerja sama yang baik, GoPay dinyatakan sebagai dompet digital yang paling banyak digunakan. Selain itu, GoPay juga memberikan fasilitas lebih untuk mahasiswa UNTAR, dengan membuat panggung kecil yang dapat digunakan untuk acara apapun, tanpa dipungut biaya apapun. Selanjutnya, peneliti menemukan masalah mengenai regulasi cashback yang diberikan oleh GoPay. Cashback yang diterima awalnya sebesar Rp 10,000,- turun menjadi Rp 5.000,- dan sekarang turun menjadi Rp 3.000,- karena adanya trial market yang dijalankan oleh GoPay. Mengenai regulasi tersebut, narasumber yang merupakan mahasiswa menjawab, bahwa ia akan tetap menggunakan GoPay berapa pun cashback nya karena GoPay memiliki kemudahan dan kecepatan yang lebih baik dibandingkan dengan member card. 
Terakhir, kepala kasir kantin UNTAR 2 menyatakan bahwa penggunaan card less dapat mempertahankan pembelian di Kantin UNTAR Kampus 1, dengan perbandingan $70 \%$ dengan 30\% diantara penggunaan GoPay dengan member card.

\section{Simpulan}

Berdasarkan penelitian yang sudah peneliti lakukan, berikut adalah kesimpulan nya:

- Penggunaan GoPay di kalangan mahasiswa untuk berbelanja di kantin UNTAR Kampus 1 ada dikarenakan GoPay memiliki persepsi manfaat yang menarik perhatian mahasiswa berupa cash back pada tiap transaksi yang berlangsung.

- $\quad$ Minat pembelian mahasiswa menggunakan GoPay di kantin UNTAR lebih besar dibandingkan dengan member card, karena GoPay memiliki persepsi kemudahan untuk di isi ulang (top up) dan cara bertransaksi yang lebih cepat menggunakan $Q R$ Code.

- Upaya yang diberikan GoPay terhadap mahasiswa di Kantin Universitas Tarumanagara didasari oleh minat GoPay untuk bekerja sama dengan Kantin UNTAR dan menjadikan UNTAR sebagai pioneer penggunaan e-payment pertama di dunia pendidikan.

\section{Ucapan Terima Kasih}

Puji syukur penulis sampaikan kepada Tuhan Yang Maha Esa atas berkat yang sudah dilimpahkannya sehingga penulis bisa menyelesaikan skripsi ini dengan tepat waktu. Selain itu, peneliti juga ingin mengungkapkan rasa terima kasih sebesarbesarnya kepada beberapa pihak yang secara langsung dan tidak langsung telah mendukung peneliti menyelesaikan laporan ini. Penelitian ini adalah salah satu syarat untuk mendapatkan gelar S1 di Fakultas Ilmu Komunikasi UNTAR dengan judul "Upaya GoPay dalam Mempertahankan Minat Pembelian Mahasiswa di Kantin UNTAR Kampus 1"

\section{Daftar Pustaka}

About GoJek. (n.d.). Agustus 25, 2019. http://www.gojek.com/about/.

Aplikasi GoJek. (n.d.). Agustus 25, 2019. http://www.gojek.com/

Bank Indonesia. 2016. Surat Edaran Bank Indonesia Nomor No.18/40/PBI/2016, Perihal Penyelenggaraan Teknologi Finansial Perkembangan.

Daftar Aplikasi dengan Pengguna Terbanyak (n.d.). 13 Desember 2019 https://iprice.co.id/trend/insights/e-wallet-terbaik-di-indonesia/

Ferdinand, Augusty. (2006). Metode Penelitian Manajemen. Semarang: Badan Penerbit Universitas Diponegoro.

Herdiansyah, Haris. (2010). Metodologi Penelitian Kualitatif Untuk Ilmu-Ilmu Sosial. Jakarta Selatan: Salemba Humanika. 
Livia Gracely, Eko Harry Susanto, Sisca Aulia: Upaya GoPay Terhadap Mahasiswa di Kantin UNTAR Kampus 1

Susanto, Eko Harry. (2010). Komunikasi Manusia: Esensi Dan Aplikasi Dalam Dinamika Sosial Ekonomi Politik. Jakarta: Mitra Wacana Media. 